\title{
Improving communication and increasing adoption of innovations in the beef industry
}

\author{
Hayley Moreland, Paul Hyland
}

\begin{abstract}
Agriculture has adopted many scientific innovations that have improved productivity. The majority of innovations in agriculture have been communicated to end users through a simple diffusion and dissemination model. However, as the science underpinning the innovations becomes more complex, research and development organizations need to look at better ways to communicate their innovation to end users. This paper examines innovations in the beef industry in Australia and investigates how complex innovations are being communicated and identifies the nature and level of communication with end users and the role of intermediaries. The findings support the need for greater involvement of end users in the innovation development process and a more vibrant two-way communication process between scientists, intermediaries and end users. The results also suggest that the traditional diffusion processes are insufficient to ensure high levels of awareness and adoption.
\end{abstract}

\section{Introduction}

The agricultural industry is capable of responding to ever-changing conditions, and in the past has been able to reduce cost of production and remain competitive due to the introduction of scientific innovations. ${ }^{1}$ These innovations in the beef industry include scientific developments in pasture management, cattle selection tools to improve feed efficiency and improving reproductive efficiency. ${ }^{2-4}$ However, increasingly, it has become important to not only react to the changing conditions but also anticipate them. ${ }^{1}$

Just as there has been a shift in focus of the beef industry from a commodity market to a differentiated market, this shift has been mirrored by the changes in research and development (R\&D) and innovation priorities. In the past, the focus has been on increasing production; however, as Barr (2003) suggests 'consumers do not eat more bread because there are more loaves on supermarket shelves' (p. 123). ${ }^{1}$ This is the same for beef production; rather than concentrating only on producing more beef, innovations need to be able to improve efficiency and differentiate products from each other. As science seeks new ways to improve and innovate agricultural production they must also discover better ways of communicating with end users. This communication is important if end users are to understand the benefits of innovations and if scientists are to understand the needs and practices of the end users. This paper examines recent 
scientific innovations in the beef industry in Australia and evaluates the communication processes and their impact on innovation adoption.

\section{Context}

The beef industry is widespread throughout most of Australia, made up of 43211 broad-acre farms involved in breeding beef cattle, ${ }^{5,6}$ spread over $65 \%$ of the country. These farms are predominantly small and medium family-owned businesses. The Australian Bureau of Agricultural and Resource Economics classes beef cattle enterprise size according the number of cattle owned by the farmers, with small and medium enterprises (SMEs) being those with less than 1600 animals $^{7}$ and 94.6\% (40 861 farms) of Australian beef farms falling into the SME category. These small and medium farms contribute $55 \%$ of the cattle sales in Australia. ${ }^{7}$ With most of the beef cattle enterprises in Australia being SMEs and supplying 55\% of the product, they are vital to the beef industry in Australia. These enterprises are generally family-owned and run enterprises that do not have internal $R \& D$ departments. Most cattle farmers breed, fatten and sell their cattle either directly to slaughter houses or sell un-fattened cattle directly to other farmers or through auctions at saleyards.

However, in recent years the increased inputs such as cost of land, supplementary feed and grain prices have caused beef production costs to increase. There are some differences between northern and southern Australia beef farming, the northern farms stock Bos Indicus (cattle adapted to harsh conditions) while the majority of southern farms stock Bos Taurus breeds. In northern regions, there are low stocking rates over extensive areas, with relatively low inputs. In southern regions, farms are smaller, with higher inputs in terms of improved pastures, fertilizer use and, in some cases, irrigation (p. xiv). ${ }^{8}$ The growing cost pressures on the beef industry have led to the following remark by National Land and Water Resources Audit (NLWRA) (p. xiv) "Decreasing commodity prices (in real terms) and increasing input prices mean that the beef industry is under constant pressure to increase the efficiency of production in order to maintain viable levels of business profitability". In looking to maintain profitability many farmers look to innovate, often using R\&D carried out by scientists in large government funded research organizations and communicated through extension officers employed by government departments responsible for agriculture and primary industries.

However in considering adopting an innovation the potential user has to be aware of it. Adoption is strongly influenced by the way the innovation is communicated, during the awareness stage and subsequently the evaluation stage. The communication of information about innovations to potential users has evolved over time as scientists learn that innovations are more likely to be adopted if the awareness strategies take into account the needs of the potential adopters. ${ }^{9}$ Although, as innovations such as genetic technologies become more complex and difficult to understand the communication process needs to evolve and become more of a two-way path rather than a unidirectional diffusion process. 
The communication of innovations from the provider to the end user is central to the innovation diffusion process. Rogers defines diffusion as 'the process by which an innovation is communicated through certain channels over time among the members of a social system' (p. 5). ${ }^{10}$ The original model of diffusion was the passive, appropriability model. ${ }^{11}$ This model was based on the research of Ryan and Gross and popularized by Rogers and forms the basis of the diffusion research in agriculture and presumes that if research and developments are high quality and have benefits, potential users would adopt them as a function of normal competitive pressure, hence the presence of an innovation would be easily communicated through the population mainly by word of mouth. ${ }^{11-14}$

The dissemination model is built on the diffusion theory by actively providing information about the innovation via change agents or intermediaries. ${ }^{15}$ These change agents behaved as an intermediary between the innovation provider and the potential user. The dissemination model was used in particular by government agents who recognized that in order to make a decision on adopting an innovation, the potential adopter goes through a decision-making process. To aid this decision-making process, potential users need more information on the innovation than just knowing it exists. However, the dissemination model did not involve the end users in a two way communication process in the design of materials to aid transfer of technical information. ${ }^{12}$ Nor does the model acknowledge that the perceived benefits of an innovation as seen by the end user are often different to the characteristics that are interesting to R\&D personnel or intermediaries. ${ }^{11,12}$

To overcome this deficiency, the dissemination model was further modified into a knowledge-utilization model, which is an active approach to diffusion of innovation. ${ }^{11}$ This model recognizes the importance of networking and active communication and the involvement of end users in the development and transfer of innovation. ${ }^{11}$ The knowledge-utilization model encourages two way communication where the end users identify and communicate problems and help decide the direction of research and development projects undertaken by researchers.

Communication plays an essential role in the innovation adoption process. Figure 1 provides a model of the innovation adoption model currently viewed by many in the beef industry. The current model has two main phases once the scientists have developed innovations. The first phase in adoption is the initiation stage, which consists of three sub-stages; awareness, evaluation, and decision. During this stage of the process, a potential user becomes aware of an innovation and makes a decision on whether to trial it or not based on available information. An awareness of an innovation is instigated either by the potential user, an intermediary, or the innovation provider. ${ }^{10,16}$ Following awareness, the innovation is evaluated by the end user. The evaluation of an innovation allows the potential user to determine whether it will complement the business, provide a solution to an operational problem, or provide a source of competitive advantage. ${ }^{17}$ The information used to evaluate the innovation may be solely researched by the potential user; however, in many cases, particularly in SMEs and agricultural operations, this stage is facilitated by an intermediary, usually a government officer or consultant. ${ }^{18-21}$ 
The implementation is the stage in Figure 1 where the user moves to incorporate the innovation into their day-to-day operations. The innovation is trialed on a small scale and evaluated as to its fit with current practices. ${ }^{22}$ During the trialing sub-stage, the potential user can identify modifications that need to be made to the innovation or to the existing practice to take full advantage of the innovation. ${ }^{10}$ Another outcome of the trial implementation may be to reject the innovation because of its failure to meet the expectations of the user. ${ }^{23,24}$ If the trial of the innovation is successful, it is assimilated into the organization, and this is the final stage of the adoption process. ${ }^{22}$ The implementation stage is often iterative, with continued experimentation and adjustment prior to full adoption.

In considering adopting an innovation, the potential user has to be aware of it, and the initiation stage is strongly influenced by the way the innovation is communicated, initially during the awareness stage and subsequently in the evaluation stage. The way that extension officers communicate information about innovations to potential users has changed over time as practitioners learnt that innovations are more likely to be adopted if the awareness strategies take into account the needs of the potential adopters. ${ }^{9}$ While some feedback occurs between end users and extension officers the feedback rarely makes it back to the scientist who developed the innovations in the first place. In part this is because extension officers are seen as advocates for the science and often act as filters. In their filtering role they choose to promote some innovations rather than others (often this is linked to funds available) and they are rarely encouraged to provide feedback to scientist or filter the feedback so it is mainly positive.

\section{Technology-push versus demand-pull communication strategies}

The models described so far in this paper have technology-push characteristics, whereby innovation-generating organizations supply innovations or research and development outcomes to potential users. ${ }^{27}$ While the technology-push models have dominated research, demand-pull also plays a role in communication. Demand-pull is where the potential user identifies an issue or problem to be resolved by innovation. ${ }^{11,17}$ In a demand-pull scenario, the firm looking to adopt an innovation instigates the communication with the innovation-producing unit. The interaction between the firms may be to locate any existing innovations that may be useful to the potential user, or it may be the first step in the development of a new product. ${ }^{11}$

Both technology-push and demand-pull modes of communication are important in the innovation adoption process as they are often the first phase in the adoption process as outlined in Figure 1. Technology-push models are the most widely researched type of communication model. ${ }^{14}$ These models are also more criticized, primarily for having pro-innovation and individual-blame biases. ${ }^{28}$ Pro-innovation bias condemns the technology-push models and in particular the diffusion model proposed by Rogers, for advocating that innovations should be diffused and adopted regardless of the needs of the potential user. ${ }^{9,13,29,30}$ Similarly, individual-blame bias argues that the focus of research into adoption examines why an individual does or does not adopt and suggests 
that individuals who choose not to adopt are resisting innovation, without acknowledging that the innovation may not fit with the potential user's system. ${ }^{13,30}$

Diffusion researchers regard those who adopt an innovation first as innovators, describing them as venturesome, while laggards, the last to adopt, are said to display a resistance to innovation. ${ }^{10}$ Diffusion researchers have acknowledged these biases and the labels are still used although they are often accompanied by a disclaimer stating that no disrespect is intended. ${ }^{10}$ An interesting issue raised by Goldenberg and Oreg is that today's laggards may be tomorrow's innovators. ${ }^{31}$ That is, they may resist innovations until a particular innovation comes along that meets their needs and has been communicated in an appropriate way and then they may be the first to adopt.

In both technology-push and demand-pull approaches good communication is essential and a balance between the two approaches is essential. Obviously, R\& D bodies want to develop innovations to demonstrate the benefits of science, in the hope that they will be at the forefront of industry trends. Bauwman et al. uses the example of Microsoft developing gadgets and innovations that may never reach the market, just because it is 'technologically possible' (p. 63). ${ }^{17}$ However, evidence from the technology-push models described also highlight a need to be aware of the needs of the user because some exciting technology is not applicable to industry. Both technologypush and demand-pull forms of communication are essential to influencing the innovation-adoption process. ${ }^{32}$

\section{Intermediaries}

Intermediaries are key communicators and facilitate the flow of information and innovations between the innovation producer and users, contributing to both the technology-push and demand-pull communication modes. Intermediaries are needed as the motivations and skills for those that produce innovations are different compared to those who are the potential users. ${ }^{25}$ Intermediaries can be a third party involved in communicating knowledge or innovations from the provider, from different sectors within an organization, government employees, private company consultants, sales staff and other individuals. ${ }^{33-35}$ Intermediaries are outstanding communicators who transfer information between innovation systems whether the systems are within or between organizations. ${ }^{36}$

In figure 1 the role of the intermediary is shown as the bridge between the research organization and the end user. More specifically, an intermediary affects the initiation stage of the innovation-adoption process. Key to the role of the intermediary is twoway communication ensuring information flow that sees the intermediary relay information from the researcher to the user and vice versa. 


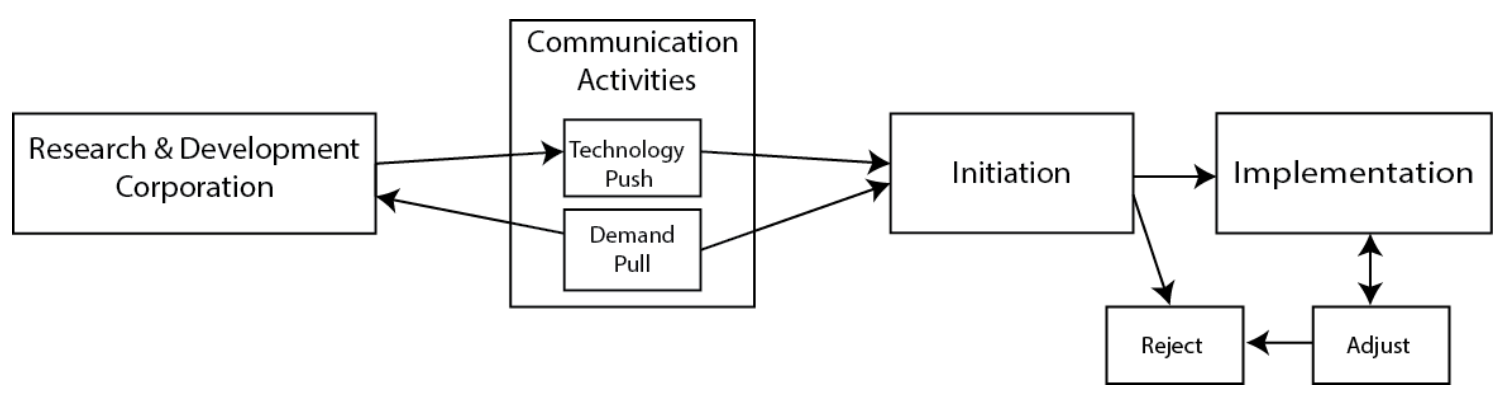

Figure 1. Communication activity interaction with the innovation-adoption process( Based on Rogers 1995).

In agriculture the firms are often small, family owned businesses and effort has been concentrated on transferring information to these firms independently. This process has commonly been termed extension. Extension is the process of transferring principles developed in universities, research stations and research groups to the general agricultural community by government funded extension agents. Increasingly, private R\&D and commercial companies are also contributing to extension, working in conjunction with and in some cases, in competition with public extension services. Marsh \& Pannell define extension as those public and private sector activities relating to technology transfer, education, attitude change, human resource development, and collection and dissemination of information. ${ }^{37}$

\section{Methods}

There was the scarcity of research on communication in innovation adoption and adoption studies that focused on the agricultural sector and the beef industry has highlighted that this context is unique and further research was required. ${ }^{38-40}$ The informants for this study (see table 1 for details) were purposefully selected for their involvement in the research and development of scientific innovations in the beef industry. The target population was experts in the field of beef industry research and development, who had a role in communication innovations. Data was collected using face-to-face, semi-structured interviews with individual informants.

A total of 25 interviews of 1 to 1.5 hours duration were conducted. All interview excerpts are referenced to a respondent group then coded to protect the anonymity of interviewees and this was a requirement of the Human Research Ethics approval process The coding used was as follows $\mathrm{R}=$ Researcher, $\mathrm{RS}=$ Department of Primary Industries Researcher, RU= University researcher), Department of Primary Industries Extension Officer (E) or Industry body (IB). Using a semi-structured interview approach the interviewees were asked to identify the key technological innovations that have been developed for the beef industry from 1992-2007, their characteristics and the communication strategies employed to transfer them to the potential users and the estimated acceptance of the identified technical innovations by beef producers, The interviews were recorded and additional notes were taken during and after the interview to ensure the depth and completeness of information gathered. Interviews were 
transcribed verbatim and transcripts were sent to the informants to review and comment on the transcript. Only one respondent indicated that some minor changes had to be made and the person was contacted by telephone to discuss and clarify the issues. The data was stored in a database using the software program QSR NVivo, which was used purely to assist the analysis process.

\begin{tabular}{|c|c|c|}
\hline Organization* & Informants & $\begin{array}{l}\text { Number of } \\
\text { informants }\end{array}$ \\
\hline Beef CRC & $\begin{array}{l}\text { Chief executive officer, Program leader } \\
\text { accelerated adoption, Chairman of the board }\end{array}$ & 3 \\
\hline \multirow[t]{2}{*}{ Universities Researchers } & $\begin{array}{l}\text { University of Queensland-Head of Animal } \\
\text { Science, Director of Research and Senior } \\
\text { Lecturer in Reproduction and Animal Medicine; }\end{array}$ & 3 \\
\hline & $\begin{array}{l}\text { University of New England-Professor of Meat } \\
\text { Science, }\end{array}$ & \\
\hline CSIRO & Senior scientist-Molecular Genetics & 1 \\
\hline $\begin{array}{l}\text { Meat and Livestock } \\
\text { Australia }\end{array}$ & $\begin{array}{l}\text { Innovation Manager, Supply chain management } \\
\text { R\&D coordinator Off farm, Supply Chain } \\
\text { Management R\&D coordinator on-farm, } \\
\text { Manager Strategic Science, Board Director }\end{array}$ & 5 \\
\hline \multirow[t]{3}{*}{$\begin{array}{l}\text { State Department } \\
\text { researchers }\end{array}$} & $\begin{array}{l}\text { NSW DPI-Principle Research Scientist (Animal } \\
\text { Science) x 2, Research Leader in Beef Genetics } \\
\text { and Improvement }\end{array}$ & 6 \\
\hline & Research Leader Animal Production, & \\
\hline & $\begin{array}{l}\text { QLD DPI-General Manager Animal Science, } \\
\text { Animal Science Leader (Beef and Sheep) }\end{array}$ & \\
\hline \multirow[t]{3}{*}{ Extension personnel } & $\begin{array}{l}\text { NSW-Beef Cattle Advisory officer, District } \\
\text { Livestock officer with beef products, Beef } \\
\text { industry leader }\end{array}$ & 6 \\
\hline & $\begin{array}{l}\text { VIC-Project manager meat and wool extension, } \\
\text { Senior Project Manager meat and wool program }\end{array}$ & \\
\hline & $\begin{array}{l}\text { QLD-Senior Extension officer-Genetics and } \\
\text { reproduction }\end{array}$ & \\
\hline \multirow[t]{2}{*}{ Commercial Company } & Sales and Marketing Manager & 1 \\
\hline & Total & 25 \\
\hline
\end{tabular}

The informants were asked to identify the most influential innovations released to the beef industry in the past 10-15 years; this was chosen to represent innovations 
recently released. The innovations were then narrowed to the key innovations by selecting the three most referenced innovations that were available commercially, that were not mandated and that were classed as technological innovations. This process identified three innovations; BREEDPLAN, Meat Standards Australia and DNA Markers commercialized for prediction of traits.

BREEDPLAN is a software program based on a quantitative model that uses individual animal, parent and sibling information to estimate the genetic potential of a particular animal. BREEDPLAN software was first released in 1984 and has continued to be updated and improved. ${ }^{41}$ There are a range of traits that are measured and converted to Estimated Breeding Values (EBVs). These EBVs are then used to compare animals within a breed to select genetically superior animals for breeding.Traits that are being assessed are growth traits, carcase traits, and reproductive traits.

DNA markers are specific sequences of DNA that identify particular genes in an organism. In the beef industry, the commercialized markers show how many favorable copies $(0,1$ or 2$)$ of the gene an animal has for a particular production trait. For example, cattle have a number of genes that influence tenderness. One such gene is the Calpain gene. If the animal has two copies of the favorable form of this gene it has the genetic potential to produce more tender beef than an animal with one positive and one negative form of the gene. In turn, an animal with 1 copy of the positive form of the gene will have a better chance of producing tender beef than an animal with 0 copies of the favorable form of the gene. The first DNA marker test was commercialized by an Australian company in 2000 allowing cattle producers to identify animals with the favorable genes by having hair, semen, blood or tissue samples tested.

Meat Standards Australia (MSA) is a meat grading system released to industry in 1999. MSA goes beyond traditional grading systems in that the meat grading occurs on the carcass. The MSA grade incorporates whole of supply chain effects to give a descriptive, quality assured end product. ${ }^{42}$ MSA was developed to increase beef consumption in Australia by increasing the consistency and predictability of tenderness in Australian beef.

The MSA grade is calculated using data from all stages of the meat production chain; including breed, sex, age, time held in pens, carcass hanging method, post mortem cooling speed and cooking method. ${ }^{42}$ The result is a grade of unsatisfactory, good everyday ( 3 star), better than everyday ( 4 star) or premium quality (5 star) for every muscle in the body according to cooking method. For example, one cut of meat may be a premium quality ( 5 star) roast, and also a good everyday ( 3 star) grill, indicating that to get the best eating experience the meat should be roasted.

All the innovations identified were evaluated against the criteria; awareness, availability optional and technological the outcomes are summarized in Table 2. 


\begin{tabular}{|lccccc|}
\hline \multicolumn{1}{|c}{ Innovation } & Total & Awareness & Availability & Optional & Technological \\
\hline BREEDPLAN & 19 & $\checkmark(76 \%)$ & $\checkmark$ & $\checkmark$ & $\checkmark$ \\
DNA Markers & 16 & $\checkmark(64 \%)$ & $\checkmark$ & $\checkmark$ & $\checkmark$ \\
MSA & 13 & $\checkmark(52 \%)$ & $\checkmark$ & $\checkmark$ & $\checkmark$ \\
Marker Assisted EBVs & 9 & $\checkmark(36 \%)$ & $x$ & $\checkmark$ & $\checkmark$ \\
NLIS & 7 & $\checkmark(28 \%)$ & $\checkmark$ & $\checkmark$ & $x$ \\
Management Strategies* & 7 & $\checkmark 28 \%)$ & $\checkmark$ & $\checkmark$ & $\checkmark$ \\
Information technology & 4 & $\times(16 \%)$ & $\checkmark$ & $\checkmark$ & $x$ \\
Feedlotting & 4 & $\times(16 \%)$ & $\checkmark$ & $\checkmark$ & $x$ \\
Sustainability Practices & 2 & $\times(8 \%)$ & $\checkmark$ & $\checkmark$ & $\times$ \\
Composites and cross breeding & 2 & $\times(8 \%)$ & $\checkmark$ & $\checkmark$ & $x$ \\
Advanced reproduction\# & 2 & $\times(8 \%)$ & $\checkmark$ & $\checkmark$ & $x$ \\
Growth Paths & 1 & $\times(4 \%)$ & $\checkmark$ & $\checkmark$ & $\checkmark$ \\
Marketing & 1 & $\times(4 \%)$ & $\checkmark$ & $\checkmark$ & $x$ \\
\hline
\end{tabular}

*Animal Management Strategies include controlled mating, yard/early weaning, drought feeding, pasture management and nutrition management.

\#Advanced reproduction includes in-vitro fertilization, cloning and spaying techniques

Table 2. Technological innovation evaluation matrix.

The key innovations were determined based on greatest level of awareness, being available for adoption, optional rather than mandated and technological rather than management innovation. Once the key innovations had been identified the interview data was inductively analyzed using a combination of pattern matching and memoing. The analysis of the way that the key technological innovations were communicated to the end users was guided by the adoption framework. The focus of communication outlined in the framework (Figure 1) were:

- Demand pull

- Technology Push

- Combination of the two

The literature suggested that the most effective communication occurs when the potential user identifies an issue that needs solving, or requests information on innovations. Therefore, positive forms of communication are demand-pull and a combination demand-pull and technology-push. Technology-push alone does not promote high levels of innovation adoption.

\section{Results}

The interview data revealed that these three communication pathways outlined in Figure 1 were not specific enough to describe the communication strategies currently used in the beef industry. A technology-push approach was the most commonly mentioned communication strategy; however, the manifestation of the technology-push 
communication differed among innovations. The results indicate that the communication processes can be seen to have two trajectories; demand-pull and technology-push, and technology-push has three stages; diffusion, dissemination and knowledge utilization.

The results revealed that BREEDPLAN and DNA markers have been communicated in a technology-push way utilizing diffusion and dissemination. The data indicates that BREEDPLAN and DNA markers have been communicated ineffectively. In contrast, MSA used the demand-pull communication path and this has a more positive effect on innovation transfer. To understand how communication can be improved and who is best positioned to act as key communicator we examine the findings from a research and industry perspective.

\section{Science Communication}

BREEDPLAN researchers focus on the attributes of the technology so it has been communicated using a technology-push approach. Initially, BREEDPLAN information was delivered using diffusion strategies.

'It's (BREEDPLAN) had exposure over a number of years and there have been a number of state organizations that are committed to tech transfer in that area... at the moment it's a technology push' (University Researcher 1).

DNA markers had similar results to BREEDPLAN, with the majority of respondents stating that DNA markers have been communicated with a technology-push approach. However, the major dissemination effort was attributed to the company that commercialized the innovation rather than agricultural extension staff

'Industry has sort of a carrier of (DNA marker) information. But you know having a commercial company interested in selling the gene marker technology, and they have certainly done a pretty good job of getting themselves involved; with website, they attend meetings, they work with MLA, they attend meat forums, and so on so they are out there promoting their product pretty well' (University Researcher 2).

But the company still used a technology push approach and did not attempt to understand the needs or the difficulties facing end users.

As many researchers have identified and become aware of the gap between science and innovation adoption they have looked to take other approaches to disseminating their findings. As a result the diffusion approach has become more focused on integrating innovations such as BREEDPLAN into cattle producers' enterprise

'And that has probably been - that would be one of my criticisms of our some of our past (BREEDPLAN) extension efforts. Including from the CRC, well we go do this research and say "OK we have done this study up at Tullimba feedlot and got this result, OK guys you should take this onboard." Whereas I think we need to be more realistic and think that once we go out there and prove ourselves scientifically that there's something there, we need to then take it to the next step and get evaluated and tested in industry' (Research Scientist 4). 
While the shift to dissemination was an improvement on the more passive diffusion approach, with BREEDPLAN as one research scientist noted diffusion did not improve the level of uptake.

'BREEDPLAN has been a major impact in providing the potential for more rapid genetic improvement, but I must say that it is still a bit disappointing in the lack of use of that technology broadly across the industry' (Research Scientist 4).

The need to make innovations such as BREEDPLAN more relevant and to ensure effective communication is supported by the view of one government researcher, who maintained that:

'In the past we've focussed on the technology (BREEDPLAN). "You must have BREEDPLAN EBVs!" And we haven't been looking how best to integrate it into the system' (Department of Primary Industries Researcher 1).

These messages will impact on both the initiation and implementation phases of adoption as the end user, while needing to understand the technology, must understand the impact of introducing the technology on their farming and breeding practices.

A key factor that leads to low adoption of an innovation is poor communication; as one research scientist commented the messages are not as clear as they could be and that this has negatively influenced the acceptance of BREEDPLAN:

'Probably the easiest thing (to do to implement BREEDPLAN) is if you have commercial herd is to actually use BREEDPLAN to help a better bull next time you buy a bull. And that is sort of a bit complicated, I guess you have got to do your research to understand what those figures actually mean. But the information is all readily available and it does actually require an effort to understand it and there is not too many experts out there that can give you reliable information on it either' (Research Scientist 4).

By targeting the one sector, the stud breeding sector, communication efforts did not create a strong demand in the initiation phase for the product across all sectors of the industry.

Perhaps more concerning is that in the communication process the messages being communicated to the industry often by scientists caused confusion and put the integrity of the innovation at risk.

'The other things (than the way the innovation was communicated) that would affect delivery are the extent to which I think people have faith in the value of these tools and I don't know that that's always as clear cut as it should be' (Research Scientist 1).

In contrast to the other key technical innovations, MSA was considered by the respondents to have been successfully communicated and so successfully adopted by end users. The approach to communicating was a true combination of demand-pull and technology-push via knowledge utilization. This collaborative communication approach may be linked to the way the research into the innovation was conducted. The initial research was driven by an industry recognized problem- declining beef 
consumption caused in part by inconsistency in beef eating quality. The solution that the science community, in collaboration with industry bodies, came up with was the MSA grading system.

'There was already a demand there (for a system to improve eating quality) and an industry need for a technology that could give that that consistency of supply of product. So it made it very easy for the scientist, as long as they did good science' (Research Scientist 2).

When MSA was developed, the innovation was introduced to the processing end of the supply chain rather than the cattle producer end. This created a demand for MSA accredited cattle throughout the supply chain and encouraged individual cattle producers, who were paid a bonus for cattle graded MSA, to use the technology.

'Most of them were in the processing sector, where the small number of people influenced by the technology transfer people, rather than having to go back to 'on farm' to deal with thousands of beef producers, it was really a matter of dealing with dozens of the meat processors' (Research Scientist 2).

So finding and leveraging the best communication channels can improve the innovation adoption, particularly when there is an economic incentive to adopt.

\section{Industry and extension communication}

Many respondents with a research background or working in research roles focused on the technology and follow a diffusion or dissemination path. Other respondents recognized that uptake could be improved by working with cattle producers more closely and that BREEDPLAN could be communicated more effectively using the knowledge utilization approach. One extension officer described his experience with promoting BREEDPLAN:

'When I came over... the department was running BREEDPLAN workshops. When I got here I said "I don't believe BREEDPLAN workshops are going to work because that (BREEDPLAN) puts a lot of people off side", people said to me um, "Mum and Dad could do this (select cattle) without BREEDPLAN therefore we don't need it". And there was a major study in the Goondiwindi area that had Herefords, Poll Herefords, that said "no, we know all about this". And a place outside Dalby was in the same boat at one stage where I did a workshop. And they said "no, we know how to do it, we don't need this information". When we changed it to bull selection (which includes BREEDPLAN), they all came and were all keen. And then it was introduced as part of that package. So that's where it really sits, not as standalone technologies' (DPI Extension Officer 6).

Similarly if there is no feedback from the end users incorporated into dissemination activities the adoption rate will suffer.

Despite the best efforts of the private company to market DNA markers, informants suggested that the DNA markers could have been communicated more effectively and more widely 
'It's been really targeted at the seed stock industry and I think to some of the commercial breeders it's, 'what the hell are they talking about?' And I don't think it has been that strongly marketed out there (in the commercial sector)' (DPI Extension Officer 4).

This lack of understanding and poor connectivity with extension officers contributes significantly to poor adoption rates. However not all extension officers are supportive of all technologies. This lack of commitment can result in mixed messages from extension workers, with some being very supportive of the innovation, while others suggest

'That they (cattle producers) shouldn't place too much relevance on them (DNA Markers) because they're going beyond just selecting for one trait, they are selecting for one gene that is affecting that trait. And that's in animal breeding that's not the right thing to do' (DPI Extension Officer 1).

The company selling the innovation have acknowledged the need to move towards communicating the markers using knowledge utilization. They are doing this by taking the approach of working with producers to identify how the technology could be implemented into their enterprise and improving the communication channels.

'The key change (in the communication of DNA markers) is moving from selling a single marker... to taking more of a solutions based approach. So working with customers to identify what their needs are. We have a small number of other customers (like large pastoral companies for example) where we do breeding programs and development activities with them, which is quite a different approach but certainly a good use of the technology' (DPI Extension Officer 7).

The consensus amongst respondents was that DNA markers have been communicated using the technology-push, dissemination approach. The company commercializing the technology has been effective in promoting the innovation by providing technical and marketing material on the benefits of using the DNA markers. However, the dissemination mode of communication was not sending clear messages to cattle producers on how to use the markers in practice on their enterprises. This has been linked to some misinterpretation by cattle producers which resulted in reduced faith in the innovation.

It is not only extension officers who can make a difference and improve the communication flow. With MSA the communication and extension programs were generously funded and supported by a number of influential people within the beef industry and companies that were able to help motivate users to take the MSA system on board.

'I think that enormous amount of effort was put in by lots and lots of people to get the processors to come on board... Enormous efforts from people that are trusted by industry, to tell people this is worth doing, this is worth getting involved in. Personal relationships were used to get it going and I think that that was enormously valuable. I think that the fact that there was $\$ 14$ million dollars behind it also helped- nothing helps innovation like a bit of money'. (Industry Body1). 
Personal relationships can be the key to establishing open communication and they can also be a constraint or more widespread communication.

There still remains a tendency to blame the end user. It was also widely thought that the messages are not being received as well as they could because cattle producers have a pre-existing negative opinion of BREEDPLAN.

'I think quite honestly it (BREEDPLAN) scares the hell out of a lot of producers. I mean you get a couple of lab coats up in front of a group of people and talking some pretty high level science, most producers are going to zone out, not because they are not interested just that the messages aren't getting through' (Industry Body 5).

While end users can form opinions very rapidly and reject technologies it is usually because the message has been skewed or was inappropriate in the first place. Scientists need to rely more on extension officers to act as intermediaries who can translate science into farming and breeding practices.

The data suggests that MSA was communicated to the processing sector through dissemination and then once the processors were interested in using the system, it was promoted to the larger community. This approach then created a demand-pull for information by cattle producers who wanted to learn how to achieve MSA status.

MSA was developed and promoted with a very clear focus and this enabled those endorsing it to develop a structured and well-planned communication strategy. This combined knowledge utilization and demand-pull approaches to communication were very effective in the communication of the innovation and promoted the adoptability of MSA. Extension officers were more convinced of the benefits of MSA and their communication activities combined with the activities of processors reinforced the positive benefits of MSA.

\section{Conclusion}

The three innovations were communicated in different ways. BREEDPLAN and DNA markers were both communicated in a technology-push way, being dominated by diffusion and dissemination communication strategies respectively. MSA was the only innovation that was communicated using a knowledge utilization approach that combined demand-pull and technology-push modes of communication. BREEDPLAN and DNA markers were not considered to have been communicated effectively for maximum innovation transfer.

In addition to the communication approaches used, the interview data highlighted the importance of the content of communication. BREEDPLAN and DNA markers did not have a clear message of how to use the innovation or a clear single outcome that will result from implementation, while MSA did. Intermediaries such as extension officers maintained that there was a need to communicate innovations as part of a solution rather than as the only solution. Both the mode of communication and the messages communicated affect the adoptability of the innovation and therefore how readily the innovations were accepted. 


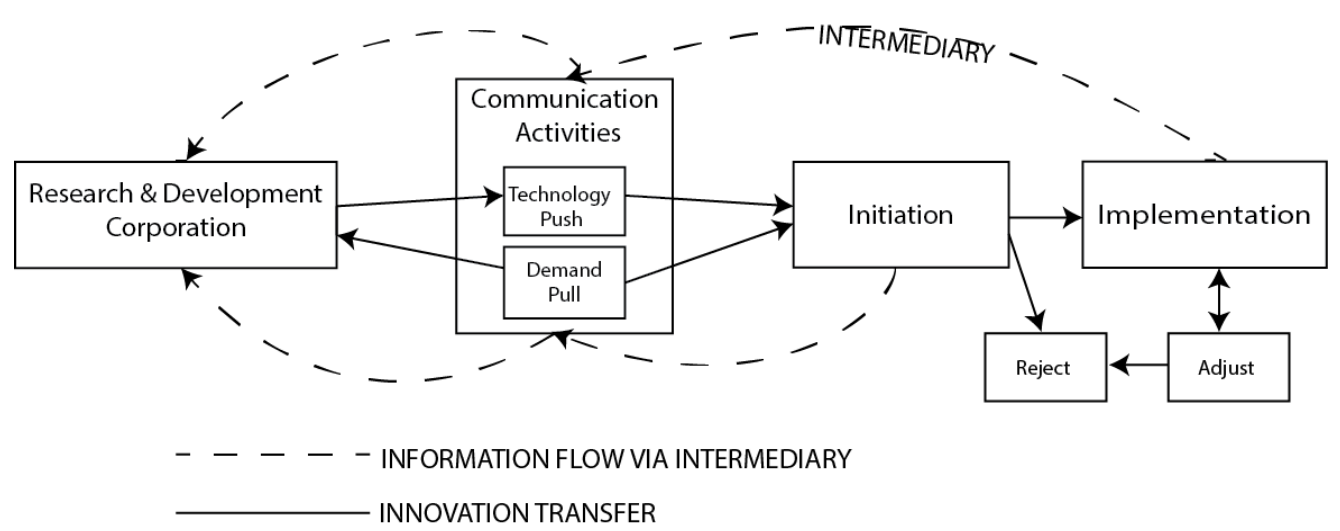

Figure 2. Communication interactions with intermediaries in the innovation-adoption process.

The complexity of a scientific innovation is not a barrier to adoption if the communication pathway is appropriate and the message is tailored to the end user and can be understood and translated by intermediaries so that it fits with the practices of end users. Intermediaries as shown in Figure 2 play an important role in both translating science into practice and as a pathway for feedback between end users and scientists. In order to identify the appropriate pathway and to craft the message so that it is meaningful to the end-user it is important to involve end-users and intermediaries early in the R\&D process. Also as this research has demonstrated if the innovation has multiple groups of end-users it is important to have a message for each group and the appropriate communication pathways. This research has also reinforced the important roles intermediaries play in communicating to end-users the benefits of scientific innovations and their application in practice. But intermediaries need a clear message if they are to assist in innovation adoption and they need to understand the importance of not creating mixed messages for the end-users. Communication may be the key to improved innovation adoption but only with the appropriate pathway and a message tailored to the end-users can it open the door to accelerated innovation uptake.

\section{Notes and references}

${ }^{1}$ N. Barr (2003), Future agricultural landscapes, Australian Planner 40(2): 123-127.

${ }^{2}$ Beef CRC (no date), Application for CRC funding, Beef CRC, Armidale.

${ }^{3}$ B.M. Bindon and N.M. Jones (2001), Cattle supply, production systems and markets for Australian beef, Australian Journal of Experimental Agriculture 41: 861-877.

${ }^{4}$ K.A. Howard, S.J. Walsh and K.S. Lamb (2004), BeefCheque - a 'dirty boots' approach to achieving profitable beef production in Gippsland, Australian Journal of Experimental Agriculture, 44(9): 851862.

5 ABARE (2006), Agricultural Economies of Australia and New Zealand. Past, Present and Future, ABARE, Canberra.

${ }^{6}$ ABARE (2006), Australian Beef Industry. Financial Performance to 2005-06, ABARE, Canberra.

${ }^{7}$ ABARE (2008), Australian Beef 08.1, ABARE, Canberra.

${ }^{8}$ NLWRA (2008), Signposts for Australian Agriculture — The Australian Beef Industry. NLWRA, Canberra.

${ }^{9}$ G. Stephenson (2003), The somewhat flawed theoretical foundation of the extension service, Journal of Extension (on line) 41(4), available at: http://www.joe.org/joe/2003august/a1.shtml. 
${ }^{10}$ E.M. Rogers (2003), Diffusion of Innovations, $5^{\text {th }}$ ed., The Free Press, New York, U.S.A.

${ }^{11}$ S.M. Camp and D.L. Sexton (1992), Technology transfer and value creation: extending the theory beyond information exchange, Technology Transfer 8(2): 68-76.

${ }^{12}$ B. Ryan and N.C. Gross (1943), The diffusion of hybrid seed corn in two Iowa communities, Rural Sociology 8: 15-24.

${ }^{13}$ E.M. Rogers (1962), Diffusion of Innovations, The Free Press, New York, U.S.A.

${ }^{14}$ A.W. Black (2000), Extension theory and practice: a review, Australian Journal of Experimental Agriculture 40(4): 493-502.

${ }^{15}$ M.D. Devine, T.E. James and T.I. Adams (1987), Government supported industry-university research centers: Issues for successful technology transfer, Journal of Technology Transfer 12(1): 27-37.

${ }^{16}$ R.A. Wolfe (1994), Organisational innovation: Review, critique and suggested research directions, Journal of Management Studies 31(3): 405-431.

${ }^{17}$ H. Bauwman, B. van den Hoof, L. van de Wijngaertand J. van Dijk (2005), Information and communication technology in organisations, Sage Publications, London, U.K.

${ }^{18} \mathrm{~J}$. Coutts and K. Roberts (2003), Extension models and best practise in extension, paper presented at the Australasia Pacific Extension Network National forum, Hobart, Australia, www.regional.org.au/au/apen.

19 J. Dart, J. Petheram and W. Straw (1998), Review of Evaluation in Agricultural Extension, Barton, ACT Australia: Rural Industries Research and Development Corporation.

${ }^{20}$ L.J. Guerin and T.F. Guerin (1994), Constraints to the adoption of innovations in agricultural research and environmental management: a review, Australian Journal of Experimental Agriculture 34: 549571.

${ }^{21}$ A. Hausman (2005), Innovativness amoung small businesses: Theory and propositions for future research, Industrial Marketing Management 34: 773-782.

${ }^{22}$ S. Gopalakrishnan and F. Damanpour (1997), A review of innovation research in economics, sociology and technology management, Omega, International Journal of Management Science 25(1): 15-28.

${ }^{23}$ A.G. Woodside and W.G. Biemans (2005), Modelling innovation, manufacturing, diffusion and adoption/rejection processes, Journal of Business and Industrial Marketing 20(7): 380-393.

${ }^{24} \mathrm{C}$. Yu and Y. Tao (2008), Understanding business-level innovation technology adoption, Technovation, in press.

${ }^{25}$ F. Damanpour J.D. Wischnevsky (2006), Research on innovation in organisations: Distinguishing innovation-generating from innovation-adopting organisations, Journal of Engineering and Technology Management 23: 269-291.

${ }^{26}$ C. Slappendel (1996), Perspectives on innovation, Organization Studies 17(1): 107-129.

${ }^{27}$ G. van Dijk and P. von Boekel (2001), Governance of innovation in animal production: new roles for science, business and the public sector, Livestock Production Science 72: 9-23.

${ }^{28}$ A.W. van den Ban and H.S. Hawkins (1996), Agricultural Extension, $2^{\text {nd }}$ ed., Blackwell Science Ltd, U.K.

${ }^{29}$ E.M. Rogers (1995), Diffusion of Innovations, $4^{\text {th }}$ ed., The Free Press, New York, U.S.A.

${ }^{30}$ T. McMaster \& D.Westall (2005), Diffusion or delusion? Challenging an IS research tradition, Information Technology and People 18(4): 383-404.

${ }^{31} \mathrm{~J}$. Goldenberg and S. Oreg (2007), Laggards in disguise: Resistance to adopt and the leapfrogging effect, Technological Forecasting and Social Change, volume in press.

${ }^{32}$ X. Li, T.J. Hess and J.S. Valacich (2008), Why do we trust new technology? A study of initial trust formation with organisational information systems, Journal of Strategic Information Systems 17: 3971 .

${ }^{33}$ L. Klerkx and C. Leeuwis (2007), Balancing multiple interests: Embedding innovation intermediation in the agricultural knowledge infrastructure, Technovation 28: 364-378.

${ }^{34}$ T. Adler, J.A. Black and J.P. Loveland (2003), Complex systems: boundary-spanning training techniques, Journal of European Industrial Training 27: 111-124.

${ }^{35}$ M. Laranja (2008), The development of technology infrastructure in Portugal and the need to pull innovation using proactive intermediation policies, Technovation, volume in press. 
${ }^{36}$ A. Kauffman and F. Todtling (2001), Science-industry interaction in the process of innovation: the importance of boundary-crossing between systems, Research Policy 30: 791-804.

${ }^{37}$ S. Marsh and D.J. Pannell (1998), The changing relationship between public and private sector agricultural extension in Australia, Rural Society 8(2): 133-151.

${ }^{38}$ C. Driedonks, S. Gregor, A. Wassenaar and E. van Heck (2005), Economic and Social Analysis of the Adoption of B2B Electronic Marketplaces: A Case Study in the Australian Beef Industry, International Journal of Electronic Commerce 9(3): 49-72.

${ }^{39}$ V. Edmondston, T. Nolan, J. Bertram, R. Sneath, F. McIntosh, J. Shorter and B.M. Burns (2004), A feedback system to promote integration, sharing of information and profitability and sustainability of all beef supply chain sectors, paper presented to Animal Production in Australia.

${ }^{40} \mathrm{~S}$. Gregor and K. Jones (1999), Beef producers online: diffusion theory applied, Information Technology and People 12(1): 71-85.

${ }^{41}$ H.-U. Graser, B. Tier, D.J. Johnston and S.A. Barwick (2005), Genetic evaluation for the beef industry in Australia, Australian Journal of Experimental Agriculture 45: 913-921.

${ }^{42}$ J. Thompson (2002), Managing meat tenderness, Meat Science 62: 295-308.

\section{Authors}

Professor Paul Hyland is a Professor in Management at Queensland University of Technology. His research focuses on business improvement and technology management. Professor Hyland has been involved in a wide range of funded research projects including an Australian Research Council Grant EU funded projects, and in recent years he has worked with several Cooperative Research Centres. He is currently working with the Cooperative Research Centre for Infrastructure and Engineering Asset Management. E-mail: paul.hyland@qut.edu.au.

Hayley Moreland has a PhD candidate from the University of Queensland. She was the recipient of Cooperative Research Centre funding for her research. Her main research focus is exploring and investigating the innovation adoption. Specifically, the level of importance supply chain factors play in technology uptake.

E-mail: hayley.robinson@qut.edu.au.

How TO CITE: H. Moreland and P. Hyland, Improving communication and increasing adoption of innovations in the beef industry, JCOM 12(02) (2013) A01. 